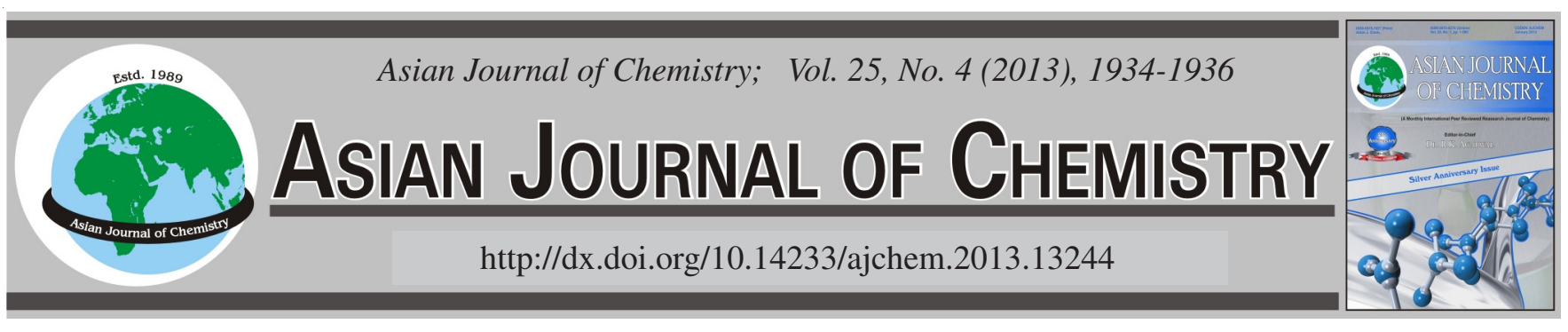

\title{
An Efficient and Eco-Friendly Solvent-Free Synthesis of $\beta$-Acetamido Ketones Using L-Proline As a Green and Reusable Catalyst
}

\author{
M. Roshani ${ }^{*}$, S. Allameh and E. Darkooti
}

Department of Chemistry, Mashhad Branch, Islamic Azad University, 91735-413, Mashhad, Iran

*Corresponding author: E-mail: drmina.roshani@yahoo.com

A simple and efficient catalytic protocol for the synthesis of $\beta$-acetamido ketones via the one-pot, four component condensation of aryl aldehydes, enolizable aryl ketones, acetyl chloride and acetonitrile using L-proline is reported. The present method offers several advantages such as high yields, short reaction times, recovery and reusability of catalyst and easy workup procedures.

Key Words: $\beta$-Acetamido ketones, Enolizable aryl ketones, Aryl aldehydes, Reusable catalyst.

\section{INTRODUCTION}

Most attention has been focused on the use of proline due to its ready availability in either L- or D-form and the highly versatile nature of its reactivity ${ }^{1-3}$. The natural amino acid L-proline is one such small molecule, which given rich dividends in ees and yields in several asymmetric transformation, such as Aldol ${ }^{4}$, Mannich $^{5}$ and Michael $^{6}$ reactions, Robinson annulations ${ }^{7}$, synthesis of amino acids ${ }^{8} \alpha$-amination of aldehydes and ketones ${ }^{9}, \alpha$-oxidation ${ }^{10}$ and $\alpha$-alkylation of aldehydes ${ }^{11}$.

$\beta$-Acetamido ketones are versatile intermediates, in that their skeletons exist in a number of biologically or pharmacologically active compounds ${ }^{12,13}$. They could easily be converted to 1,3 -amino alcohols ${ }^{14}$, which are utilized for the synthesis of several antibiotics ${ }^{15}$. $\beta$-Acetamido ketones are usually prepared through of $\beta$-aminoketones ${ }^{16}$, Michael addition to $\alpha, \beta$-unsaturated ketones ${ }^{17}$ or photoisomerization of phthalimides ${ }^{18}$. The best-known route for the synthesis of these compounds is the one-pot condensation of an aldehyde, an enolizable ketone, acetyl chloride and acetonitrile, originally reported by Iqbal and co-workers. A few catalysts including $\mathrm{CoCl}_{2}{ }^{19}$, cobalt(II) acetate ${ }^{20}, \mathrm{SiO}_{2}-\mathrm{H}_{2} \mathrm{SO}_{4}{ }^{21}$, triflate salts ${ }^{22}$, zeolite ${ }^{23}$, iodine ${ }^{24}, \mathrm{Bicl}_{3}{ }^{25}$, $\mathrm{ZrOCl}_{2} \cdot 8 \mathrm{H}_{2} \mathrm{O}^{26}$ and heteropolyacids ${ }^{27}$ have already been applied for the synthesis of $\beta$-acetamido ketones, using this method. Although various procedures are reported for synthesis of $\beta$ acetamido ketones, some drawbacks such as low yields, prolonged reaction time, use of costly reagents or catalysts and use of toxic organic solvents, exist. Thus, the development of an environmentally benign methodology for the synthesis of $\beta$-acetamido ketone derivatives is in great demand.

It is therefore of interest to examine the behavior of Lproline as catalyst in solvent-free conditions for synthesis of $\beta$-acetamido ketones. To the best of our knowledge, condensation of aryl aldehydes, enolizable aryl ketones, acetyl chloride and acetonitrile in the presence of a catalytic amount of L-proline for the synthesis of $\beta$-acetamido ketones has not been reported in literature. In this paper we wish to report the use of L-proline for synthesis of $\beta$-acetamido ketone derivatives (Scheme-I).
(1)<smiles>[X]c1ccc(C=O)cc1</smiles>

(2)<smiles>[Y]c1ccccc1C(C)=O</smiles>

(3)<smiles>[X]c1ccc(C(=O)CC(NC(C)=O)c2ccc([X])cc2)cc1</smiles>

(5) 
Initially, in order to find the optimal amount of catalyst, the reaction of $p$-nitrobenzaldehyde $(1 \mathrm{mmol})$, acetophenone (1 mmol), acetyl chloride $(1.5 \mathrm{mmol} 0.3 \mathrm{~mL})$ and acetonitrile ( $3 \mathrm{~mL}$ ) under solvent-free condition at $110^{\circ} \mathrm{C}$ in the presence of various amount of L-proline were used as a model reaction. The best result has been obtained at $35 \mathrm{~mol} \%$ of catalyst (Table-1).

TABLE-1

COMPARISION OF THE AMOUNT OF L-PROLINE AND YIELDS FOR SYNTHESIS OF N-[1-(4-NITROPHENYL)3-OXO-3-PHENYLPROPYL]ACETAMID (5h)

\begin{tabular}{cccc}
\hline Entry & Catalyst $(\mathrm{mol} \%)$ & Time $(\min )$ & Yield $(\%)$ \\
\hline 1 & 0 & 300 & Nil \\
2 & 5 & 120 & 30 \\
3 & 15 & 80 & 46 \\
4 & 30 & 30 & 72 \\
5 & 35 & 30 & 85 \\
6 & 40 & 40 & 70 \\
\hline
\end{tabular}

The generality of this process was demonstrated by the wide range of substituted aryl aldehydes and enolizable aryl ketones to synthesize the corresponding products in high yields
(Table-2). Unlike some previously reported methods, the present method does not require toxic organic solvents to produce the $\beta$-acetamido ketone derivatives. All the products were characterized by NMR, IR and melting point and also by comparison with the data reported in literature.

The suggested mechanism of the reaction can be followed according to the steps in Scheme-II.

We also investigated the reusability of the catalyst. For this purpose after completion of the model reaction, the cold water was added. The catalyst is soluble in cold water and could therefore be recycled as the filtrate. The catalyst was recovered by evaporation of the water and washed with diethylether and reused in model reaction without appreciable reduction in the catalytic activity.

\section{EXPERIMENTAL}

Melting points were determined on an Electrothermal type 9100 melting point apparatus. IR spectra were recorded using a 4300 Shimadzu spectrophotometer with $\mathrm{KBr}$ plates. ${ }^{1} \mathrm{H}$ NMR spectra were recorded on a Bruker DR X500 spectrometer. The products (5a-l) were isolated and characterized by

\begin{tabular}{|c|c|c|c|c|c|c|c|}
\hline & ITHESIS & ETAMII & NES US & $\begin{array}{l}-2 \\
\text { ROLINE UN }\end{array}$ & SOLVENT & ONDITIO & \\
\hline Entry & $X$ & $\mathrm{Y}$ & Product & Time (min) & Yield (\%) & m.p. $\left({ }^{\circ} \mathrm{C}\right)$ & Lit. m.p. $\left({ }^{\circ} \mathrm{C}\right)$ \\
\hline 1 & $\mathrm{H}$ & $\mathrm{H}$ & $5 \mathbf{a}$ & 50 & 67 & $103-105$ & $104-105^{19}$ \\
\hline 2 & $2-\mathrm{Cl}$ & $\mathrm{H}$ & $5 \mathbf{b}$ & 40 & 85 & $295-297$ & $295-296^{19}$ \\
\hline 3 & $4-\mathrm{Cl}$ & $\mathrm{H}$ & $5 c$ & 25 & 90 & $145-146$ & $149-150^{19}$ \\
\hline 4 & $3-\mathrm{Br}$ & $\mathrm{H}$ & $5 d$ & 25 & 80 & $239-242$ & $239-240^{19}$ \\
\hline 5 & $4-\mathrm{Br}$ & $\mathrm{H}$ & $5 e$ & 25 & 89 & $160-162$ & $162-164^{19}$ \\
\hline 6 & $2-\mathrm{NO}_{2}$ & $\mathrm{H}$ & $5 f$ & 30 & 63 & $137-140$ & $139-140^{19}$ \\
\hline 7 & $3-\mathrm{NO}_{2}$ & $\mathrm{H}$ & $5 g$ & 30 & 74 & $115-117$ & $119-121^{19}$ \\
\hline 8 & $4-\mathrm{NO}_{2}$ & $\mathrm{H}$ & $5 \mathbf{h}$ & 25 & 85 & $152-154$ & $155-156^{19}$ \\
\hline 9 & 4-Me & $\mathrm{H}$ & $5 \mathbf{i}$ & 45 & 45 & $209-211$ & $210-211^{19}$ \\
\hline 10 & 4-OMe & $\mathrm{H}$ & $5 \mathbf{j}$ & 40 & 55 & $107-110$ & $109-110^{19}$ \\
\hline 11 & $4-\mathrm{Cl}$ & $4-\mathrm{Cl}$ & $5 \mathbf{k}$ & 25 & 92 & $140-143$ & - \\
\hline 12 & $4-\mathrm{Cl}$ & $4-\mathrm{NO}_{2}$ & 51 & 25 & 94 & $115-118$ & - \\
\hline
\end{tabular}<smiles>[X]c1cccc(C(C)=O)c1</smiles><smiles>O=C(O)C1CCCN1</smiles><smiles>[Y]c1ccc(C(C)(O)N2CCC[C@H]2C(=O)O)cc1</smiles><smiles>C=COC</smiles><smiles>[Y]c1ccc(C(C)=[N+]2CCC[C@H]2C(=O)O)cc1</smiles><smiles>[X]c1ccccc1C=O</smiles><smiles>[X]c1ccc(C(=O)CC(c2ccccc2)[N+]2=C(C(C)=O)CC[C@H]2C(=O)O)cc1</smiles><smiles></smiles><smiles>[X]c1ccc(C(CC(=O)c2cccc([Y])c2)NC(C)=O)cc1</smiles>

Scheme-II 
comparison of physical and spectral data with those of known samples.

General procedure for the preparation of $\boldsymbol{\beta}$-acetamido ketones (5a-l): A mixture of aryl aldehydes (1 mmol), enolizable aryl ketones $(1 \mathrm{mmol})$, acetyl chloride $(1.5 \mathrm{mmol}$ $0.3 \mathrm{~mL})$, acetonitrile $(3 \mathrm{~mL})$ and L-proline $(35 \mathrm{~mol} \%)$ was heated at $110^{\circ} \mathrm{C}$ for $25-50 \mathrm{~min}$. After completion of reaction (monitored by TLC), the reaction mass was added to a stirred mixture of ice and water. The product was filtered, washed with diethylether and recrystallized from ethanol/ethylacetate to give compounds (5a-l) in high yields.

\section{Selected specteral data}

N-[1-(4-Nitrophenyl)-3-oxo-3-phenylpropyl]acetamid (5h): ${ }^{1} \mathrm{H}$ NMR $\left(500 \mathrm{MHz}, \mathrm{CDCl}_{3}\right) \delta: 2.2\left(\mathrm{~s}, 3 \mathrm{H}, \mathrm{CH}_{3}\right), 3.6(\mathrm{dd}$, $\left.1 \mathrm{H}, \mathrm{CH}_{2}\right), 3.9\left(\mathrm{dd}, 1 \mathrm{H}, \mathrm{CH}_{2}\right), 5.8(\mathrm{~m}, 1 \mathrm{H}, \mathrm{CH}), 7.1(\mathrm{~m}, 1 \mathrm{H}$, $\mathrm{NH})$, 7.6-8.5 (m, 9H, Ar-H). IR (KBr disc, $\left.\mathrm{v}_{\max }, \mathrm{cm}^{-1}\right)$ : 3289 $\left(\mathrm{NH}_{2}\right), 1686(\mathrm{CO}), 1650(\mathrm{CO})$.

N-[1-(4-Methylphenyl)-3-oxo-3-phenylpropyl] acetamid (5i): ${ }^{1} \mathrm{H} \mathrm{NMR}\left(500 \mathrm{MHz}, \mathrm{CDCl}_{3}\right) \delta: 2.0\left(\mathrm{~s}, 3 \mathrm{H}, \mathrm{CH}_{3}\right)$, $2.5\left(\mathrm{~s}, 3 \mathrm{H}, \mathrm{CH}_{3}\right), 3.4\left(\mathrm{dd}, 1 \mathrm{H}, \mathrm{CH}_{2}\right), 3.6\left(\mathrm{dd}, 1 \mathrm{H}, \mathrm{CH}_{2}\right), 5.5(\mathrm{~m}$, $1 \mathrm{H}, \mathrm{CH}), 7.1(\mathrm{~m}, 1 \mathrm{H}, \mathrm{NH}), 7.3-8.1(\mathrm{~m}, 9 \mathrm{H}, \mathrm{Ar}-\mathrm{H})$. IR $(\mathrm{KBr}$ disc, $\left.v_{\max }, \mathrm{cm}^{-1}\right): 3288\left(\mathrm{NH}_{2}\right), 1686(\mathrm{CO}), 1650(\mathrm{CO})$.

N-[1-(4-Chlorophenyl-4-nitropropiophenone)-3-oxo-3phenylpropyl]acetamid (5l): ${ }^{1} \mathrm{H} \mathrm{NMR}\left(500 \mathrm{MHz}, \mathrm{CDCl}_{3}\right) \delta$ : $2.2\left(\mathrm{~s}, 3 \mathrm{H}, \mathrm{CH}_{3}\right), 3.7\left(\mathrm{dd}, 1 \mathrm{H}, \mathrm{CH}_{2}\right), 3.9\left(\mathrm{dd}, 1 \mathrm{H}, \mathrm{CH}_{2}\right), 5.8(\mathrm{~m}$, 1H, CH), 7.1 (m, 1H, NH), 7.6-8.5 (m, 8H, Ar-H). IR (KBr disc, $\left.v_{\max }, \mathrm{cm}^{-1}\right)$ : $3295\left(\mathrm{NH}_{2}\right), 1689(\mathrm{CO}), 1650(\mathrm{CO})$.

\section{Conclusion}

It should be noted that, this method is effective for the preparation of $\beta$-acetamido ketones from the one-pot, four component condensation of aryl aldehydes, enolizable aryl ketones, acetyl chloride and acetonitrile using L-proline.

\section{REFERENCES}

1. A.S. Bommarus and K.M. Polizzi, Chem. Eng. Sci., 61, 1004 (2006)

2. P.I. Dalko and L. Moisan, Angew. Chem. Int. Ed., 43, 5138 (2004).

3. S. Vijaikumar, A. Dhakshinamoorthy and K. Pitchumani, Appl. Catal., 340, 25 (2008)

4. A.B. Northrup and D.W.C. MacMillan, J. Am. Chem. Soc., 124, 6798 (2002).

5. A. Cordova, Acc. Chem. Res., 37, 102 (2004).

6. D. Enders and A. Seki, Synlett, 26 (2002).

7. T. Bui and C.F. Barbas, Tetrahedron Lett., 41, 6951 (2000).

8. A. Cordova, W. Notz, G. Zhong, J. Betancort and C.F. Barbas III, J. Am. Chem. Soc., 124, 1842 (2002).

9. R.O. Duthaler, Angew Chem. Int. Ed., 42, 975 (2003).

10. Y. Hayashi, J. Yamaguchi and T. Sumiya, Angew. Chem. Int. Ed., 43, 1112 (2004).

11. N. Vihnola and B. List, J. Am. Chem. Soc., 126, 450 (2004).

12. J.R. Casimir, C. Turetta, L. Ettouati and J. Paris, Tetrahedron Lett., 36, 4797 (1995).

13. A.G. Godfrey, D.A. Brooks, L.A. Hay, M. Peters, J.R. McCarthy and D. Mitchell, J. Org. Chem., 68, 2623 (2003).

14. D. Enders, M. Moser, G. Geibel and M.C. Laufer, Synthesis, 2040 (2004).

15. K. Kobinata, M. Uramoto, M. Nishii, H. Kusakabe, G. Nakamura and K. Isono, Agric. Biol. Chem., 44, 1709 (1980).

16. P. Dallemagne, S. Rault, H. Cugnon de Sévricourt, Kh.M. Hassan and M. Robba, Tetrahedron Lett., 27, 2607 (1986).

17. P.W. Jeffs, R. Redfearn and J. Wolfram, J. Org. Chem., 48, 3861 (1983).

18. M.R. Paleo, D. Domínguez and L. Castedo, Tetrahedron Lett., 34, 2369 (1993).

19. I.N. Rao, E.N. Prabhakaran, S.K. Das and J. Iqbal, J. Org. Chem., 68, 4079 (2003).

20. E.N. Prabhakaran and J. Iqbal, J. Org. Chem., 64, 3339 (1999).

21. M.M. Khodaei, A.R. Khosropour and P. Fattahpour, Tetrahedron Lett., 46, 2105 (2005).

22. G.R. Pandey, R.P. Singh, A. Garg and V.K. Singh, Tetrahedron Lett., 46, 2137 (2005).

23. R.P. Bhat, V.P. Raje, V.M. Alexander, S.B. Patil and S.D. Samant, Tetrahedron Lett., 46, 4801 (2005).

24. B. Das, K. Ravinder Reddy, R. Ramu, P. Thirupathi and B. Ravikanth, Synlett, 1756 (2006).

25. R. Ghosh, S. Maity and A. Chakraborty, Synlett, 115 (2005).

26. R. Ghosh, S. Maiti, A. Chakraborty, S. Chakraborty and A.K. Mukherjee, Tetrahedron, 62, 4059 (2006).

27. L. Nagarapu, S. Kantevari, V.N. Cheemalapati, S. Apuri and N.V. Kumari, J. Mol. Catal. A, 264, 22 (2007). 